\title{
Risk Management Approach and Banks' Portfolio Investment Performance in Nigeria
}

\author{
OSAYI, Valentine Igbinedion, $\mathrm{PhD}^{1} \quad$ DIBAL, Hyeladi Stanley ${ }^{2} \quad$ EZUEM, Moyotole Daniel ${ }^{2}$ \\ 1. Lecturer, Department of Banking and Finance, Federal University Wukari, PMB 1020 Taraba State, Nigeria \\ 2. Lecturer, Department of Banking and Finance, Federal University Wukari, PMB 1020 Taraba State
}

\begin{abstract}
The study examined risk management approach and banks' portfolio investment performance in Nigeria. The study hypothesized that there is no relationship between risk management and banks' portfolio investment performance in Nigeria. Employing secondary data based on a 5 year annual reports and financial statements of accounts of 10 Deposit Money Banks (DMBs) in Nigeria and using the Generalized Method of Moment (GMM), the result shows a negative but significant relationship between risk management and banks' portfolio investment performance measured by Return on Asset (ROA) while the explanatory variables were measured by credit risk (CRD) doubtful and non performing loans (NPLS), liquidity risk (LQR) measured by current ratio and market risk (MKR) measured by interest rate. In the light of the foregoing findings and using the result of the tstatistic, the study rejects the null hypothesis and concludes that a significant relationship exists between risk management approach and banks' portfolio investment performance and thus recommends the need for banks to practise prudential risks management approach as risk management is critical in the banking sector in order to improve on their portfolio investment performance so as to protect not just both the stakeholders and shareholders' interest but also the national economic growth and general macroeconomic stability and business development.
\end{abstract}

Keywords: Banking Sector, Financial Statement, Portfolio Performance, Risk Management.

DOI: $10.7176 /$ RJFA/10-6-10

Publication date:March $31^{\text {st }} 2019$

\subsection{Introduction}

The banking industry has experienced huge and dramatic losses in the past decades occasioned by risk management failures. Banks that had been performing well suddenly announced large losses due to credit risk exposures that turned sour, interest rate positions taken, or derivative exposures that may or may not have been assumed to hedge balance sheet risk. According to Santomero (1997), commercial banks have in response to risk management, almost universally embarked upon an upgrading of their risk management approaches and control systems in order to ensure that investors' return and safety of their investment is assured.

By definition, risk is the chance of an asset (financial) suffering a loss. It could also be defined as the potential that a given threat will exploit vulnerabilities of an asset or group of assets to cause loss or damage to the asset. In this sense, Dipo (2008), defined banking risk as those threats that may impact the assets (loan) or processes of banks. According to Dipo (2008), risk management is the process of identifying vulnerabilities and threats to an organization's assets in achieving business objectives and deciding what counter - measures if any, to take in reducing the risk to an acceptance level. Risk can be accepted, rejected, reduced or transferred.

Modern banks provide liquidity on demand to depositors and supply funds to borrowers through loans and lines of credit (Kashyap, 2002). Accordingly, banks' risk (liquidity) management involves maintaining a store of liquid assets and access to various borrowing to guard against unexpected cash shortfalls (Loutskina 2011, Loutskina \& Strahan 2009). According to Adrian and Shin (2010), recent financial innovations such as securitization as well as changes in liability structure, notably, an increased dependence on short term wholesale funding have had a profound impact on modern banks' liquidity management.

Coincidental to this activity, and in part because of our recognition of the industry's vulnerability to financial risk, the central bank of Nigeria (CBN), with the support of other regulatory authorities has been involved in an analysis of financial risk management processes in the financial sector. Through the past financial year, on-site visits were conducted to review and evaluate the risk management systems and the process of risk evaluation that is in place. In the banking sector, system evaluation was conducted covering many of Nigeria's mega banks and quasi-money center of deposit money banks (DMBs), as well as a number of major investment banking firms. These results were then presented to a much wider array of banking firms for reaction and verification.

In order to appraise and weigh up the soundness and reliability of banking industry, the information on connection between fluctuations in banking industry and the risk which is faced by banking sector is important. Appalling financial conditions can deteriorate the value of the bank's portfolio, engendering liquidity and credit losses, which ultimately reduce profits of the banks. Therefore, a sound and reliable banking system dishes up as a significant feed for accomplishing economic growth all the way through the mobilization of monetary 
resources, placing them to dynamic use and transforming various risks.

The lessons leant from financial crisis are to open awareness of the government and business people on the important role of implementing good risk management in Nigeria. Thus, as a way out of the tide, the CBN on July 6, 2004 introduced measures to make the entire banking system a safe, sound and stable environment that could sustain public confidence in it (Owojori, Akintoye \& Adidu., 2011). According to the then CBN Governor, it is now time to set up a structure that creates a strong base relative to the kind of economy we are operating where banks become channels to do proper intermediation (The Obasanjo Economic Reforms on the Banking sector, 2005). Hence, in order to adhere partly to the Basel II 2004 regulations, a 13-point agenda to stabilize the base of the banking sector was put in place from which a compulsory recapitalization requirement of N25billion for a commercial bank operating in Nigeria is required to possess.

Though, the Nigerian banking sector has been undergoing continuous reform process since 1999 directed at improving the capacity and health of the Nigerian banks. The first major exercise was the assessment of the risk asset quality of banks which led to the removal of eight CEOs and the injection of N600 billion into the banks (BGL 2010) in order to get the banks to lend again.

However, the economic bail out provided the banks with cash and capital, the banks need to strengthen themselves for future success and a way out is an entrenchment of sound risk management framework. It is in the light of the foregoing that the study seeks to examine the impact of risk management approaches on banks' portfolio investment performance in Nigeria.

\subsection{Literature Review}

\subsection{Conceptual Clarifications}

Portfolio refers to the securities (assets) held by an investor (bank) or other financial institutions. The management of such assets following certain principles and procedures is what is referred to as portfolio management. Portfolio management also mean efficient and prudent management of a bank's assets and liabilities in order to seek some optimum combination of income or profit, liquidity, and safety. A bank's portfolio of assets consists of loans, traded securities, liquidity reserves and many other items refinanced by debt and equity. It is the current practice today to judge soundness of a financial institution by looking at accounting data, which are directly observable, and most of the current bank supervision procedures like capital requirements and reports to regulatory agencies are based on accounting values. The actual market value of the assets, that reveals more information on the bank's financial health, is not directly observable.

\section{Risk and Uncertainty}

Risk in investment analysis, is the unpredictability of future returns from an investment. Risk is defined as something happening that may have an impact on the achievement of objectives, and it includes risk as an opportunity as well as a threat (Audit Office, 2000). The concept of risk may also be defined as the possibility that the actual return may not be same as expected. In other words, risk refers to the chance that the actual outcome (return) from an investment portfolio will differ from an expected outcome. With reference to a bank, risk may be defined as the possibility that the actual outcome of a financial decision may not be same as estimated. The risk may be considered as a chance of variation in portfolio investment return. Investment portfolios having greater chances of variations are considered more risky than those with lesser chances of variations.

Risk should be differentiated from uncertainty; Risk is defined as a situation where the possibility of happening or non-happening of an event can be quantified and measured: while uncertainty is a situation where this possibility cannot be measured. Thus, risk is a situation where probabilities can be assigned to an event on the basis of facts and figures available regarding the decision. Uncertainty, on the other hand, is a situation where either the facts and figures are not available, or the probabilities cannot be assigned.

The nature of banking business contains an environment of high risk. It is so risky in the sense that it is the only business wherein proportion of borrowed funds is far higher than the owners' equity (Owojori et al., 2011). The banking business, in comparison to other types of human endeavour is entirely exposed to risks. Banks no longer simply receive deposits and make loans; they also operate in a rapidly innovative sector with a lot of pressure mount for profit which urges them for continuous product or service development to cross-sell and up sell to satisfy customers' shareholders. Risks are complex and since one single activity can involve several risks, Luy (2010) asserts that risks contain risks. Banking risks are classified into credit risk, market risk, and operational risk (Basel Committee on Bank supervision). However, Santomero, (1997) identify six types of risks - systematic or market risk, operational risk, and legal risk. Crouhy, Galai and Mark (2006) also made another classification of bank risk to include market risk, credit risk, liquidity risk, operational risk, legal risk, business risk, strategic risk, and reputational risk. 


\section{Credit Risk}

According to Luy (2010), credit risk arises whenever a lender is exposed to loss from a borrower, counterparty, or an obligator who fails to honour their debt obligation as they have contracted. Colquitt (2007), posits that this loss may derive from deterioration in the counterparty's credit quality, which consequently leads to a loss to the value of the debt. According to Crouhy, et al., (2006), the borrower defaults when he is unwilling to fulfill the obligations. Credit failure in banks is not new or a rare occurrence, they affect their liquidity position as well as cash flows and profits. Hence, Greuning and Bratanovic (2009), maintain that it is a biggest threat to any bank performance and the principal cause of bank failures.

According to Owojori et. al. (2011), available statistics from liquidated banks clearly showed that inability to collect loans and advances extended to customers and creditors or companies related to directors or managers was a major contributor to the distress of liquidated banks in Nigeria. When this occurred, a number of banking licenses were revoked by the Central Bank of Nigeria $(\mathrm{CBN})$. As Nigerian Deposit Insurance Corporation (NDIC) reports of various years indicate, many banks had their ratios of performing credits that were less than $10 \%$ of loan portfolios. The impact of this risk on banking business is poor asset quality arising from high level of non-performing loans and ultimately low yield on risk assets; financial loss due to increased loan loss provisions and charges on impaired assets; impairment of shareholders' funds. Banks face a degree of contingent credit risk in setting the interest rate on a loan commitment. Specifically, banks often add a risk premium based on its current assessment of the creditworthiness of the borrower. A case in point is when the borrower may be judged AAA credit risk rating paying 1\% above prime rate. Suppose however, that over the one-year commitment period the borrowing firm gets into difficulty; its earnings decline such that its creditworthiness is downgraded to BBB. Bank's problem is that the credit risk premium on the commitment had been preset to the AAA level for the one-year commitment period. To avoid being exposed to dramatic decline in borrower creditworthiness over the commitment period, most banks include an adverse material change in conditions clause by which bank can cancel or reprice a loan commitment. However, exercising such a clause is really a last resort tactic for a bank because it may put the borrower out of business and result in costly legal claim for the breach of contract.

\section{Counterparty Risk}

Counterparty risk comes from non-performance of a trading partner. The non-performance may arise from counterparty's refusal to perform due to an adverse price movement caused by systematic factors, or from some other political or legal constraint that was not anticipated by the principals. Counterparty risk is like credit risk, but it is generally viewed as a more transient financial risk associated with trading than standard creditor default risk. This risk could lead to financial losses due to the default of a trading counterparty. In addition, counterparty's failure to settle a trade can arise from other factors beyond a credit problem. Counterparty risks can be reduced by engaging only in transaction with approved counterparties and such risks should be reported to management for decision-making.

\section{Market Risk}

This is the risk of asset valued change associated with systematic factor. According to Santomero (1997), market risk by its nature can be hedged but cannot be diversified away completely. Two market risks that are of concern to the banking sector are interest rates and relative value of currencies. The banking operation is solely dependent on these as it impacts on their portfolio performance. For instance, most banks track interest rate risk closely. They measure and manage the firm's vulnerability to interest rate variation, even though they cannot do so perfectly. At the same time, international banks with large currency positions closely monitor their foreign exchange risk and try to manage, as well as limit, their exposure to it.

\section{Liquidity and Funding Risk}

Liquidity risk can be described as the risk of a funding crisis, such as unexpected event in the form of large charge off, loss of confidence, or a crisis of national proportion like existence crisis (Santomero, 1997). It is the sudden surge in liability withdrawals that may require a bank to liquidate some assets in a very short period of time and at a less than fair market price or value. Liquidity risk can be avoided by ensuring sufficient capital base and adequate investment in liquid assets that can easily be converted to cash at little or no costs. Funding risk may be defined as the risk that a bank will be unable to purchase or otherwise obtain the necessary funds to meet its obligations as they fall due. (These obligations might, for example, take the form of maturing deposits or drawings under committed facilities.) Funding difficulties may arise when, in order to meet sudden or unusually large withdrawals of funds, a bank is forced to rely on less stable, purchased deposits for a greater than normal proportion of its funding requirements. This may strain the willingness of the market to supply funds at competitive rates and may (perhaps wrongly) convey a signal that the bank is facing serious problems. If a bank cannot meet customers' request for immediate funds, it runs the risk of failure. Apart from insolvency, it could 
lead to reputational risk for the bank. Even if a bank has a positive net worth, illiquidity can still drive it out of business. Risk management here centers on liquidity facilities and portfolio investment performance structure. Recognizing liquidity risk leads the banks to recognize liquidity itself as an asset, and portfolio design in the face of illiquidity concerns as a challenge.

\section{Operational Risk}

This is associated with the problems of accurately processing, settling, and taking or making delivery on trades in exchange for cash. It also arises in record keeping, processing system failures and compliance with various regulations. As such, individual operating problems are small probability events for well-run organizations but they expose a firm to outcomes that may be quite costly. This risk can also arise from the malfunctioning or break down of existing technology, auditing, monitoring and other support system being unable to perform. It is the risk of incurring financial loss as a result of inadequacies or failures in operational processes, system or staff. Major sources of operational risk include: operational processes, Information and Communication Technology (ICT), outsourcing activities, service providers, strategy implementation, mergers and acquisitions, fraud, error, regulatory compliance, staff, social and environmental factors. This adversely affect bank customers resulting in attendant loss in market share, financial loss and reputational damage, and ultimately being unable to deliver a strong business performance that meets stakeholders' expectations. However, banks can manage or reduce this risk by establishing a central processing centre specialising in various operation areas, and the migration of some activities which were hitherto handled at the branches, the introduction of a functional reporting structure to the operations job families to allow for effective supervisory control of the operations of the bank, development of policies and other frameworks such as outsourcing Policy; operational loss recording, accounting \& reporting policy, Continuous deployment of a self-assessment programme to allow process owners to identify control weaknesses with a view to taking proactive remedial actions, automation and re-engineering of processes, stepping up operational risk awareness training and programmes, and monitoring and managing key risk indicators (KRIs) in processes, products and activities.

\section{Legal Risks}

Legal risks are endemic in financial contracting and are separate from the legal ramifications of credit, counterparty, and operational risks. New statutes, tax legislation, court opinions and regulations can put formerly well-established transactions into contention even when all parties have previously performed adequately and are fully able to perform in the future. For example, environmental regulations have radically affected real estate values for older properties and imposed serious risks to lending institutions in this area. A second type of legal risk arises from the activities of an institution's management or employees. Fraud, violations of regulations or laws, and other actions can lead to catastrophic loss, as recent examples in the thrift industry have demonstrated.

All financial institutions face all these risks to some extent. Non-principal or agency activity involves operational risk primarily. Since institutions in this case do not own the underlying assets in which they trade, systematic, credit and counterparty risk accrues directly to the asset holder. If the latter experiences a financial loss, however, legal recourse against an agent is often attempted. Therefore, institutions engaged in only agency transactions bear some legal risk, if only indirectly.

\subsection{Bank Risk Management Approaches.}

Risk management can be seen as procedures or mechanisms put in place to reduce or avoid risks. The standard economic theory maintains that managers are supposed to maximize their expected profit without regard to the variability around its expected value. However, Santomero (1995) listed four distinct rationales for risk management. These are managerial self-interest, the non-linearity of the tax structure, the cost of financial distress, and the existence of capital market imperfection.

The banking industry has long viewed the problem of risk management as the need to control four of the above risks which make up most, if not all, of their risk exposure, viz., credit, interest rate, foreign exchange and liquidity risk. While they recognize counterparty and legal risks, they view them as less central to their concerns. Where counterparty risk is significant, it is evaluated using standard credit risk procedures, and often within the credit department itself. Likewise, most bankers would view legal risks as arising from their credit decisions or, more likely, proper process not employed in financial contracting.

The risks contained in the bank's principal activities, i.e., those involving its own balance sheet and its basic business of lending and borrowing, are not all borne by the bank itself. In many instances the institution will eliminate or mitigate the financial risk associated with a transaction by proper business practices; in others, it will shift the risk to other parties through a combination of pricing and product design (Santomero, 1997).

It is in the wisdom of the banking firms not to engage in businesses in a manner that unnecessarily imposes risk upon it; nor absorb risk that can be efficiently transferred to other participants. Rather, it only manages risks at the firm level that are more efficiently managed there than by the market itself or by their owners in their own 
portfolios. Bank risk management approach focuses on only those risks that are uniquely a part of bank's array of services.

Oldfield and Santomero (1997) grouped risk facing all financial institutions into three separable types, from a management perspective. These are:

1. Risks that can be eliminated or avoided by simple business practices,

2. Risks that can be transferred to other participants, and,

3. Risks that must be actively managed at the firm level.

Common risk avoidance practices include: the standardization of process, contracts and procedures to prevent inefficient or incorrect financial decisions, the construction of portfolios that benefit from diversification across borrowers and that reduce the effects of any one loss experience in another and also, the implementation of incentive-compatible contracts with the institution's management to require that employees be held accountable.

Table 1: Risk types and Management Approach

\begin{tabular}{|c|c|c|}
\hline $\mathbf{S} / \mathbf{N}$ & Risk Types & Management Approach \\
\hline 1 & $\begin{array}{l}\text { Credit Risk: should a borrower } \\
\text { default, both principal and interest } \\
\text { payments are at risk. It is measured } \\
\text { with the use of financial ratio. }\end{array}$ & $\begin{array}{l}\text { Loan sales and rescheduling diversify some credit risk by } \\
\text { exploiting the law of large numbers in their asset investment } \\
\text { portfolio. Diversification across assets exposed to credit risk } \\
\text { reduced the overall credit risk in the asset portfolio and thus } \\
\text { increase the probability of partial or full repayment of principal } \\
\text { and / or interest. Diversification reduces firm specific credit risk } \\
\text { but this cannot reduce systematic credit risk. }\end{array}$ \\
\hline 2 & $\begin{array}{l}\text { Liquidity Risk: this is when liability } \\
\text { holders demand cash immediately. } \\
\text { That is, put their financial claims back } \\
\text { to the bank. }\end{array}$ & $\begin{array}{l}\text { Through borrowing additional funds or sell assets to meet the } \\
\text { demand for the withdrawal of funds. }\end{array}$ \\
\hline 3 & $\begin{array}{l}\text { Interest Rate Risk: the risk incurred } \\
\text { by a bank when the maturities of its } \\
\text { assets and liabilities are mismatched. }\end{array}$ & $\begin{array}{l}\text { Through refinancing and by matching the maturity of their } \\
\text { assets and liabilities. }\end{array}$ \\
\hline 4 & $\begin{array}{l}\text { Market Risk: this is the risk incurred } \\
\text { in trading assets to liabilities due to } \\
\text { changes in interest rates, exchange } \\
\text { rates and other assets prices. }\end{array}$ & $\begin{array}{l}\text { Limiting the position taken by banks on volatile securities could } \\
\text { reduce this risk. }\end{array}$ \\
\hline 5 & $\begin{array}{l}\text { OBS Risk: risk resulting from } \\
\text { contingent assets and liabilities } \\
\text { activities. }\end{array}$ & $\begin{array}{l}\text { OBS is a risk management approach to resolve other risk a bank } \\
\text { is exposed to such as credit risk, interest rate risk, foreign } \\
\text { exchange risk, etc. Products like letters of credit, loan } \\
\text { commitment, mortgage servicing contracts, positions in } \\
\text { forwarding, futures, swaps, options, and other derivatives } \\
\text { securities. For example credit derivative unbundles default risk } \\
\text { from the other features of a loan }\end{array}$ \\
\hline 6 & \multicolumn{2}{|c|}{$\begin{array}{l}\text { Technology Risk: the risk incurred by a bank when their technological } \\
\text { investments do not produce anticipated cost savings in economies of scale or } \\
\text { scope. It can be measured by examining the bank's excess capacity, redundant } \\
\text { technology, organizational and bureaucratic inefficiencies (red tape). }\end{array} \begin{array}{l}\text { date systems ande of technology } \\
\text { in use. }\end{array}$} \\
\hline 7 & $\begin{array}{l}\text { Operation Risk: the risk that existing } \\
\text { technology or support systems may } \\
\text { malfunction or break down. }\end{array}$ & $\begin{array}{l}\text { quick response to issue, increasing staff strength and training } \\
\text { for staff. }\end{array}$ \\
\hline 8 & $\begin{array}{l}\text { Foreign Exchange Risk: the risk that } \\
\text { foreign exchange rate changes can } \\
\text { affect the value of a bank's assets and } \\
\text { liabilities located abroad. }\end{array}$ & $\begin{array}{l}\text { the bank matches its assets and liabilities in each foreign } \\
\text { currency. Then the bank will be fully hedged when it holds } \\
\text { foreign assets and liabilities of exactly the same maturities }\end{array}$ \\
\hline
\end{tabular}

Source: Adapted from Osayi \& Kasimu, 2016.

\subsection{Risk Management and Banks' Portfolio Performance}

Increasing shareholders' return by optimizing bank performance is one major objective of bank management. The objective often comes at the cost of increasing risk. According to Tandelilin, Kaaro, Mahadwartha and Supriyatna, (2007), Bank faces various risks such as interest risk, market risk, credit risk, off balance sheet risk, technology and operational risk, foreign exchange risk, country risk, liquidity risk, and insolvency risk. The bank's motivation for risk management comes from those risks which can lead to bank underperformance. Issues 
of risk management in banking sector have greater impact not only on the bank but also on the entire economy (Tandelilin et al, 2007).

Banks with better risk management procedures and implement them have some advantages: (i) It is in line with obedience function toward the rule; (ii) It increases their reputation and opportunity to attract wide range of customers in building their portfolio of fund resources; (iii) It increases their efficiency and profitability. Cebenoyan and Strahan (2004), find evidence that banks which have advanced in risk management have greater credit availability, rather than reduced risk in the banking system. The greater credit availability leads to the opportunity to increase the productive assets and bank's profit. In realizing profit from their portfolio investments, banks must be able to effectively manage and reconcile the conflicting objectives of safety, liquidity and profitability of their portfolio investment performance.

\section{Reconciling the Conflicting Objectives in Bank Portfolio Management}

Liquidity and safety are primary considerations while profitability is subsidiary. For a bank to earn more profits there is need to strike a balance between liquidity and safety. According to Anyanwu (1993), these goals (solvency, liquidity, profitability) of bank portfolio management conflict with one another and can easily be seen by reflecting on the fact that a bank could be perfectly liquid only if it held its assets in cash, but then it would earn no profits. Or again, if the bank grants risky loans, it might increase its profits but it will also increase its potential for going bankrupt (insolvency).

Liquidity: liquidity being the ease with which an asset can be converted into cash (medium of exchange) without loss and minimum delay is very vital in the operations of commercial banks. Considering the liabilities of the bank payable with short notice, the bank must be liquid (holding assets in cash and other liquid forms) enough to meet those claim as they are demanded. Excess liquidity will imply low profitability, contrarily, if liquidity is ignored for profitability, there may be danger of safety for the bank. In ensuring a balance between these three conflicting objectives, high degree of safety must be ensured. The amount of liquid assets the bank can keep depends on the availability and cost of borrowing.

Safety: because of the uncertain and risky (default and decline in prices of debt obligation) nature of the operations of commercial banks, it must ensure safety for its assets. But following this strictly will imply low income because of minimum risk in investment decisions.

Profitability: while the bank needs money to meets running costs and other expenses, it must be mindful of its investment and ensure that it is relatively liquid to meets its expenses and other obligations as they fall due.

\subsection{Theoretical Review}

\section{The Commercial Loan Theory or Real Bill Doctrine}

It holds that banks should lend only on short-term, self-liquidating, productive loans (commercial paper) (Lloyd, 1945). This is because it is believed that banks liabilities are payable on demand, and it cannot meet these obligations if its assets are tied up for long period of time. Hence the need for a bank to have a constant flow of cash and other liquid assets in order to maintain its own liquidity and this can be achieved only if its lending activities are of short-term maturity. Following this, the central bank will only lend to the banks on the securities of such short-term loans.

\section{The Anticipated Income Theory}

This was developed by H. V. Prochnow in 1944 on the basis of extending term loans by the US commercial banks. The theory asserts that a bank should make long-term and non-business loans since even a 'real bill' is repaid out of the future earnings (anticipated income) of the borrower. The theory is of the view that regardless of the nature and character of the borrower's business, the bank plans the liquidation of the term-loan (a loan between 1 to 5 years period) from the anticipated income of the borrower. Following this, the bank grant loan not on the basis traditional bank lending principles, but against the hypothetication of machinery, stock and even immovable property (anticipated earnings). This principle encourages banks to give subprime loans and engage in lending activities that contravenes their maturity match. The theory asserts that if anticipated income is the true source of bank-loan repayment, then there is no reason to confine bank lending to the traditional commercial loan. What is critical at issue is the borrower's ability to repay the loan out of future earnings, nothing more (Herbert, 1949).

\section{Liability Management Theory}

This theory opines that since a bank can borrow from the money market (certificate of deposits, call money, borrowings from other commercial and central banks) that there is no need to keep liquid assets and grant only self liquidating loans. This theory explains how a bank manages its liabilities so that they become a source of liquidity. Liability management is a concept well suited for large banks than small banks because small banks do not have the necessary access to the money market needed to engage in liability management. Different from the 
traditional approach (of selling secondary reserves assets: treasury bills and bankers acceptance) to a bank funding itself when there is a decline in deposit and an increase for loans, it borrow funds it needs by means of money market instruments. For example, the bank might borrow and use it to pay unexpected deposit withdrawals or it might issue new certificates of deposits to accommodate the loan demands of customers.

\section{The Modern Portfolio Theory (MPT)}

The Modern Portfolio Theory, (MPT) is credited to an American economist named Harry Markowitz who developed a theory of portfolio choice in the 1950s which allows investors to analyse risk relative to their expected return. Markowitz's theory is today known as the Modern Portfolio Theory (MPT). The MPT is a theory of investment which attempts to maximize portfolio expected return for a given amount of portfolio risk, or equivalently minimize risk for a given level of expected return, by carefully choosing the proportions of various assets. Although the MPT is widely used in practice in the financial industry, in recent years, the basic assumptions of the MPT have been widely challenged.

The Modern Portfolio Theory (MPT) is an improvement upon traditional investment models, which is an important advancement in the mathematical modelling of finance. The theory encourages asset diversification to hedge against market risk as well as risk that is unique to a specific company. The theory (MPT) is a sophisticated investment decision approach that aids an investor to classify, estimate, and control both the kind and the amount of expected risk and return; also called Portfolio Management Theory. Essential to the portfolio theory are its quantification of the relationship between risk and return and the assumption that investors must be compensated for assuming risk. Portfolio theory departs from traditional security analysis in shifting emphasis from analyzing the characteristics of individual investments to determining the statistical relationships among the individual securities that comprise the overall portfolio (Edwin \& Martins 1997).

The MPT mathematically formulates the concept of diversification in investing, with the aim of selecting a collection of investment assets that has collectively lower risk than any individual asset. The possibility of this can be seen intuitively because different types of assets often change in value in opposite ways. But diversification lowers risk even if assets' returns are not negatively correlated-indeed, even if they are positively correlated.

More technically, the MPT models an asset return as a normally distributed function (or more generally as an elliptically distributed random variable), define risk as the standard deviation of return, and models a portfolio as a weighted combination of assets so that the return of a portfolio is the weighted combination of the assets' returns. By combining different assets whose returns are not perfectly positively correlated, MPT seeks to reduce the total variance of the portfolio return. MPT also assumes that investors are rational and markets are efficient.

The fundamental concept behind the MPT is that assets in an investment portfolio should not be selected individually, each on their own merits. Rather, it is important to consider how each asset changes in price relative to how every other asset in the portfolio changes in price.

\subsection{Empirical Review}

The subject of risk management and banks' portfolio investment performance has attracted the attention of researchers both locally and internationally such that produced different results.

Adeusi, Akeke, Adebisi, and Oladunjoye (2013), examined risk management and financial performance of banks in Nigeria. Adopting a panel data estimation technique, their findings revealed an inverse relationship between financial performances of banks and doubt loans, and capital asset ratio was found to be positive and significant. This finding implies that the higher the managed funds by banks the higher the performance of their portfolio investments.

In the same vein, Kim and Santomero (1988) examined the responsibility of bank capital regulation in controlling solvency risk. By employing mean-variance model, they found capital ratios unproductive way to restrict bank's insolvency risk. According to Bauer \&Ryser (2004), regulatory restrictions, debt ratio, volatility of risky assets, size of liquidation costs and spread between deposit rate and riskless interest rate are the significant constraints that compel bank's hedging decisions.

Similarly, Kolapo, Ayeni and Oke (2012) examined credit risk and commercial banks' performance in Nigeria using panel model analysis. The result showed that the effect of credit risk on bank performance is crosssectional invariant. That is the effect is similar across banks in Nigeria. Though the degree to which individual banks are affected was not captured by the method of analysis utilized.

Also, Olusanmi, Uwuigbe and Uwuigbe (2015) investigated the effect of risk management on Banks financial performance in Nigeria. The study employed Ordinary Least Square (OLS) regression technique to test the formulated hypothesis. Their findings showed the existence of a negative non significant relationship between risk management and bank's performance measured by return on equity.

In another study, Olawale (2015) examined the effect of credit risk on the performance of commercial banks in Nigeria. Using the ratio of loan and advances to total deposit, the result reveals that there is a significant 
relationship between bank performances in terms of profitability and credit risk management which is loan performance.

Additionally, Irani, Ruston and Meisenzahl (2015) examined the impact of banks' liquidity risk management on secondary loan sales. They tracked the dynamics of banks loan share ownership in the secondary market using data from the Shared National Credit Program which is a credit register of syndicated bank loans administered by the US regulators. Using a loan-year fixed effects approach to analyze the 2007-2009 financial crises as a market-wide liquidity shock and control demand. They found that banks with greater reliance on wholesale funding at the onset of the crisis were more likely to exit loan syndicates during the crisis.

Finally, Ahmed, Akhtar and Usman (2011), investigated risk management practices and Islamic banks in Pakistan. They used credit, operational and liquidity risk as dependent variables while size, leverage, NPLs ratio, capital adequacy and asset management were utilized as explanatory variables for the period of four years from 2006 - 2009. Using multiple regression analysis, the results indicated that size of Islamic banks have a positive and statistically significant relationship with financial risk (credit and liquidity risk), whereas its relation with operational risk was found to be negative and not significant.

\subsection{Methodology}

\subsection{Research Design}

The research design for the study is causal and longitudinal in that it involves measuring the influence of explanatory variables on the dependent variables for a given set of data collected over a period of time.

\subsection{Sources of Data}

The study utilizes annual financial reports and statement of account (data) of ten (10) Deposit Money Banks in Nigeria between 2010 and 2014.This period is particularly significant to this study as it marked a recovery phase for Nigerian banks, having just emerged from the global financial crisis of 2008/2009.

\subsection{Hypothesis}

The hypothesis for the study is formulated in the null form below:

$\mathbf{H}_{01}$ : There is no relationship between risk management approach and banks' portfolio investment performance in Nigeria.

\subsection{Model Specification}

In line with prior studies in the field of risk management such as Kolapo, Ayeni and oke (2012), who investigated credit risk and commercial bank performance in Nigeria. The model for this study is econometrically specified thus:

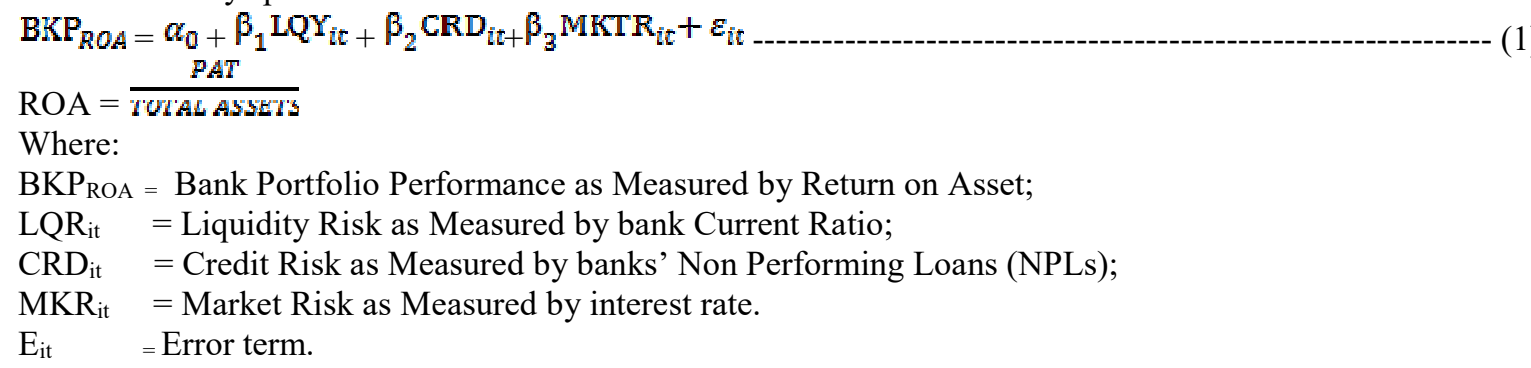

\subsection{Tool for Empirical Data Analysis}

The method of data analysis for this study is the Generalized Method of Moment (GMM) using the Eview 8.0 statistical econometric software package. Other related test such as descriptive test statistics was also carried out in it. The descriptive test statistics is important to determine the normality of the dataset used. The GMM is adopted for this study due to its versatility and suitability in measuring market risk. 


$\begin{array}{lcccc}\begin{array}{l}\text { 4.0 Result of Empirical Analysis } \\ \text { Table 2: Estimation Result for Descriptive Statistics }\end{array} & & \\ & \text { BKP } & \text { LQR } & \text { CRD } & \text { MKR } \\ \text { Mean } & 0.014293 & 1.948785 & 2254088 . & 17.70105 \\ \text { Median } & 0.013091 & 1.099196 & 273690.8 & 17.96500 \\ \text { Maximum } & 0.052622 & 12.49571 & 14084352 & 29.80000 \\ \text { Minimum } & -0.055948 & 0.916045 & 8810.100 & 7.750000 \\ \text { Std. Dev. } & 0.019309 & 2.749561 & 3858143 . & 5.044325 \\ \text { Skewness } & -1.195462 & 3.015936 & 1.740755 & 0.114057 \\ \text { Kurtosis } & 7.209967 & 10.57044 & 4.761459 & 3.103149 \\ & & & & \\ \text { Jarque-Bera } & 31.25379 & 124.9266 & 20.29819 & 0.083568 \\ \text { Probability } & 0.000000 & 0.000000 & 0.000039 & 0.959077 \\ & & & & \\ \text { Observations } & 32 & 32 & 32 & 32\end{array}$

Source: Authors' computation using E-view 8.0 output, (2018).

From the descriptive Statistic in table 1, it can be seen that BKP and LQR oscillate around the mean because of low mean value which is also confirmed by the values of standard deviation. But for CRD, the mean value is high with a very high Standard Deviation (SD) implying that CRD is far from the mean. Using JarqueBera Statistic for test of normality of the data, it is discovered that the variable, MKR passed the normality test and is statistically significant at $5 \%$ level. This is further confirmed by the probability value of 0.959077 . The implication of this is that the data is normally distributed and the estimation result reliable.

Table 3: Regression Result

Dependent Variable: BKP

Method: Generalized Method of Moments

Date: 07/29/18 Time: 14:12

Sample(adjusted): 232

Included observations: 31 after adjusting endpoints

No prewhitening

Bandwidth: Fixed (3)

Kernel: Bartlett

Convergence achieved after: 1 weight matrix, 2 total coef iterations

Instrument list: C BKP(-1) LQR CRD MKR

\begin{tabular}{crrrr}
\hline \hline Variable & Coefficient & Std. Error & t-Statistic & Prob. \\
\hline C & 0.077390 & 0.015394 & 5.027274 & 0.0000 \\
BKP(-1) & -0.193136 & 0.138519 & -1.394293 & 0.1750 \\
LQR & -0.000892 & 0.000618 & -1.442510 & 0.1611 \\
CRD & $-6.91 \mathrm{E}-10$ & $2.87 \mathrm{E}-10$ & -2.404395 & 0.0236 \\
MKR & -0.003212 & 0.000779 & -4.120752 & 0.0003 \\
\hline \hline R-squared & 0.609536 & Mean dependent var & & 0.013336 \\
Adjusted R-squared & 0.549465 & S.D. dependent var & 0.018843 \\
S.E. of regression & 0.012648 & Sum squared resid & 0.004159 \\
Durbin-Watson stat & 2.028766 & & $9.19 \mathrm{E}-29$ \\
\hline \hline
\end{tabular}

Source: Author's Computation using E-view 8.0 output, (2018).

\subsection{Interpretation of Result}

The results of the estimations are presented in the table above. The regression results using the Generalized Method of Moment (GMM) revealed that the independent variables explained the systematic variation in Bank Portfolio Performance (BKP) to the tune of 60.95\% implying the other $39.05 \%$ could not be explained by the independent variables. For the fitness of the model, the Adjusted R-squared of 54.94\% shows that the model is well fitted. This implies that the variables specified in the model are proper for providing explanation for the objective of the study. The DW shows the absence of auto-correlation. The implication of this is that the results from the analysis are reliable as they are not spurious or nonsensical. The J-Statistic of 9.19E-29 shows that the model is ridiculously good as it shows strong goodness of fit of the model.

\subsection{Discussion of Findings}

A cursory look at the t-statistic in table 2 reveals that only MKR and CRD are statistically significant in 
providing explanation for variation (changes) in BKP, this is shown by the t- values of -4.1207 and -2.4043 with a probability value of 0.0003 and 0.0236 . They are statistically significant at 5\% level. The other variables LQR and BKP(-1) are not significant. The coefficient value for MKR shows that a unit change in MKR will cause a $0.3 \%$ proportionate change in the amount of the dependent variable BKP. For CRD, a unit change in CRD will lead to $-6.91 \mathrm{E}-10$ percentage changes in BKP. For LQR, a unit change in LQR will lead to $0.08 \%$ change in BKP(-1).

The implication of these findings is that risk management is pivotal to banks' portfolio investment performance whether negative or positive depending on the risk management approach adopted by the banks. These findings are somewhat consistent with Olusanmi, Uwuigbe and Uwuigbe (2015) who found a negative non significant relationship between risk management and banks performance using return on equity as measure of bank performance. The point of divergent however, is that this study found a negative but significant relationship between risk management and banks' portfolio investment performance which validates existing findings including Olawale (2015).

\section{Empirical Validation of Hypothesis Formulated and Implications}

The t-statistic in table 2 for the three explanatory variables was used to validate the formulated hypothesis for the study. The critical t-statistic value from the statistical table at $95 \%$ confidence interval and 12 degrees of freedom is 2.179. The value is less than two of the three computed t-statistic of $1.4425,2.4044$ and 4.1208 respectively for Liquidity risk (LQR), credit risk (CRD) and market risk (MKR). Meanwhile, the t-statistic decision rule on test of hypothesis is to reject the null hypothesis and accept the alternate hypothesis when the computed $t$-value is greater than the tabulated t-value or decide otherwise when the computed t-value is less than the tabulated t-value. In the light of the foregoing, the study therefore rejects the null hypothesis and concludes that there is significant relationship between risk management approach and banks' portfolio investment performance in Nigeria.

\subsection{Conclusion and Recommendation}

Two major conclusions are drawn from the study. First, lots of factors influence banks' portfolio investment performance in Nigeria. Risk management if wrongly approached can contribute to deteriorating or worsening of banks' portfolio of assets. However, if risk management approach is effectively and timely engaged, it has the potentials of ameliorating any deteriorating assets in banks' portfolio investment performance. This is more so as better risk management in terms of managed fund, reduction in cost of bad and doubt loans and market risk results in better banks portfolio investment performance. Arising from the foregoing conclusions the study recommends thus:

- Banks should practise prudential risk management approach in order to safeguard their assets so as to protect both the stakeholders and shareholders' interests.

- Regulators should ensure that both on-site and off-site supervision of banks are effectively carried out in order to quickly detect any deteriorating asset in banks' portfolio investment performance.

- The Central Bank of Nigeria (CBN) should ensure that risk management framework released to banks is strictly enforced to assist banks in their business of financial intermediation which is crucial to their portfolio investment performance in particular and the economy in general.

\section{References}

Adeusi, S. O., Akeke, N. I., Adebisi, O. S. \& Oladunjoye, O. (2013). Risk management and financial performance of banks in Nigeria. Journal of Business and Management, 14(6), 52-56.

Adrian, T. \& Shin, H. S. (2010). Liquidity and leverage. Journal of Financial Intermediation, 19, 418-437.

Ahmed, N., Akhtar, M. F \& Usman, M. (2011). Risk management practices and Islamic banks: an empirical investigation from Pakistan. Interdisciplinary Journal of Research in Business, 1(6), 50 - 57.

Anyanwu, J.C. (1993). Monetary economics: Theory, policy and institutions. Onitsha, Nigeria: Hybrid Publishers Ltd.

Cebenoyan, A. S., \& Strahan, P. E. (2004). Risk Management, Capital Structure and Lending at Banks, Journal of Banking and Finance 28, 19-43.

Colquitt, J. (2007). Credit Risk Management: How to Avoid Lending Disasters \& Maximize Earnings. 3rd Edition. McGraw-Hill. USA.

Crouhy, M.; Galai, D. \& Mark,. (2006). The Essentials of Risk Management. McGraw-Hill. USA.

Dipo, B. (2008). Risk management in banking. The Nigerian Accountant, The Institute of Chartered Accountants of Nigeria, October/December, 41(1), 22 - 31. www.ican-ngr.org.

Edwin, J. E, \& Martin, J. G (1997). Modern portfolio theory, 1950 to date. Journal of Banking and Finance, 21, 1743-1759.

Greuning, H.V. \& Bratanovic, S. B. (2009). Analyzing Banking Risk: A Framework for Assessing Corporate 
Governance and Risk Management. 3rd Edition. The World Bank. Washington, USA.

Markowitz, H. (1952). ]Portfolio selection. Journal of Finance,

Irani, R. M \& Meisenzahl, R. R (2015). Loan sales and bank liquidity risk management: evidence from a U.S credit register, finance and economic discussion series 2015-001.

Kasimu, A. (2016). Risk management approach to bank portfolio management (unpublished PhD seminar paper) University of Benin, Benin City, Nigeria.

Kolapo, T. F., Ayeni, R. K. \& Oke, M. O. (2012). Credit risk and commercial banks' performance in Nigeria: a panel model approach. Australian Journal of Business and Management Research, 2(2), 31-38.

Luy, D. D. (2010). Evaluation of Credit Risk Management Policies and Practices in a Vietnamese Joint-Stock Commercial Bank ${ }^{e e}$ s Transaction Office. Business Economics and Tourism.

NDIC (2007). Annual Report and Accounts of Banks Submit.

Olawale, L. S (2015). The effect of credit risk on the performance of commercial banks in Nigeria. African Journal of Accounting, Auditing and Finance, 4(1), 10-22.

Olusanmi, O., Uwuigbe, U.,\& Uwuigbe, O. R (2015). The effect of risk management on bank's financial performance in Nigeria. Journal of Accounting and Auditing: Research \& Practice. 2015(2015),1-7.

Osayi, V. I. (2016). Risk management approach to bank portfolio management (unpublished PhD seminar paper) University of Benin, Benin City, Nigeria.

Osayi, V. I, Kasimu, A \& Nkwonta, C. H (2018). Financial market derivatives and the performance of deposit money banks in Nigeria. International Journal of Economics, Commerce and Management, 6(11), 382-396.

Owojori, A. A., Akintoye, R. I., \& Adidu, A. F. (2011). The challenge of risk management in Nigerian banks in the post consolidation era. Journal of Accounting and Taxation, 13(2), 23-31.

Santomero, A. (1995). Financial Risk Management: The Whys and Hows. Journal of Financial Markets, Institutions and Investments, 4, 1995.

Santomero, A. M. (1997). Commercial Banking Risk Management: an Analysis of the Process. The Wharton Financial Institutions Center. USA. Available in www form $<$ http://fic.wharton.upenn.edu/fic/papers/95/9511.pdf >, viewed 20.06.2010.

Tandelilin, E., Kaaro, H., \& Mahadwartha, P.A., Supriyatna, (2007). Corporate governance, risk management, and bank performance: Does type of ownership matter? EADN WORKING PAPER 34.

The Obasanjo Economic Reforms Banking Sector (2005). Abuja Federal Ministry of Information and National Orientation. 